\title{
Potential IFN $\gamma$ Modulation of Inflammasome Pathway in Chlamydia trachomatis Infected Synovial Cells
}

\author{
Simone Filardo ${ }^{1, *,+}+\mathbb{C}_{\text {, Marisa Di Pietro }}{ }^{1,+}{ }^{+}$, Federica Frasca ${ }^{2}$, Fabiana Diaco ${ }^{1}$, Mirko Scordio ${ }^{2}$, \\ Guido Antonelli ${ }^{2}$, Carolina Scagnolari ${ }^{2}$ D and Rosa Sessa ${ }^{1}$ \\ 1 Section of Microbiology, Department of Public Health and Infectious Diseases, "Sapienza” University, \\ 00185 Rome, Italy; marisa.dipietro@uniroma1.it (M.D.P.); fabiana.diaco@uniroma1.it (F.D.); \\ rosa.sessa@uniroma1.it (R.S.) \\ 2 Laboratory of Virology, Department of Molecular Medicine, Istituto Pasteur Italia, "Sapienza” University, \\ 00185 Rome, Italy; federica.frasca@uniroma1.it (F.F.); mirko.scordio@uniroma1.it (M.S.); \\ guido.antonelli@uniroma1.it (G.A.); carolina.scagnolari@uniroma1.it (C.S.) \\ * Correspondence: simone.filardo@uniroma1.it \\ + Co-first Simone Filardo and Marisa Di Pietro.
}

Citation: Filardo, S.; Di Pietro, M.; Frasca, F.; Diaco, F.; Scordio, M.; Antonelli, G.; Scagnolari, C.; Sessa, R. Potential IFN $\gamma$ Modulation of Inflammasome Pathway in Chlamydia trachomatis Infected Synovial Cells. Life 2021, 11, 1359. https://doi.org/ $10.3390 /$ life11121359

Academic Editor: Milan Kolář

Received: 11 November 2021 Accepted: 4 December 2021 Published: 7 December 2021

Publisher's Note: MDPI stays neutral with regard to jurisdictional claims in published maps and institutional affiliations.

Copyright: (c) 2021 by the authors. Licensee MDPI, Basel, Switzerland. This article is an open access article distributed under the terms and conditions of the Creative Commons Attribution (CC BY) license (https:// creativecommons.org/licenses/by/ $4.0 /)$.

\begin{abstract}
Following a Chlamydia trachomatis infection, the host immune response is characterized by its recognition via Toll-like and Nod-like Receptors, and the subsequent activation of interferon (IFN)- $\gamma$-mediated signaling pathways. Recently, the inflammasome-mediated host cell response has emerged to play a role in the physiopathology of C. trachomatis infection. Here we investigated, for the first time, the interaction of IFN- $\gamma$ and inflammasome in an in vitro model of $C$. trachomatis-infected primary human synovial cells. Chlamydial replication as well as the expression of caspase-1, IL-1 $\beta$, as well as IL-18 and IL-6, were assayed. Our results demonstrated the inhibitory activity of IFN- $\gamma$ by interfering with the inflammasome network through the downregulation of caspase-1 mRNA expression. In addition, the ability of $C$. trachomatis to hinder the inflammasome pathway favoring its intracellular survival within synovial cells, was observed. Overall, our data suggest a potential mechanism of immune evasion by $C$. trachomatis in synovial cells, that may be contested by IFN- $\gamma$.
\end{abstract}

Keywords: Chlamydia trachomatis; synovial cells; inflammasome; IFN- $\gamma$

\section{Introduction}

Chlamydia trachomatis, an obligate intracellular pathogen, is the leading cause of bacterial sexually transmitted diseases worldwide, with more than 130 million new cases per year [1]. C. trachomatis genital infection manifests as urethritis and cervicitis in women, and urethritis in men, although it is often asymptomatic, leading to chronic complications like reactive arthritis $(\operatorname{ReA})[2-4]$.

It is well known that C. trachomatis infects mainly the epithelial cells of the genital tract, but it can also replicate into different cell types, including synovial cells, human placental trophoblasts, and testicular human Sertoli cells [5-10]. Following chlamydial infection, the host cell response begins with the activation of a complex network of immune receptors and their unique downstream signaling pathways, resulting in the induction of proinflammatory cytokines involved in either the elimination of $C$. trachomatis or tissue damage related to chronic inflammatory state. In particular, Toll-like receptors (TLRs), TLR2, TLR3 and TLR4, and oligomerization domain (NOD)-like receptors (NLRs), NOD1, as well as the respective downstream signaling pathways, like NFkb, IRF9 and MyD88, have been identified in the immune recognition of $C$. trachomatis in several in vivo and in vitro models [5,7-11].

The ability of $C$. trachomatis to infect synovial cells, as evidenced by the presence of chlamydial inclusions in human synovial fibroblasts [11], suggested its potential direct role in the development of ReA. Chlamydial inclusion is unique among intracellular pathogens 
and represents a chlamydial survival strategy since it provides a protected vacuole where C. trachomatis replicates [3,12]. Indeed, the C. trachomatis developmental cycle occurs within the inclusion, and it is characterized by two alternating forms, the extracellular infectious form called the elementary body (EB), and the intracellular replicative and metabolically active form called the reticulate body (RB) [12]. Under stressful conditions, C. trachomatis fails to complete its developmental cycle, generating persistent forms which remain inside the host cell for a long time due to their ability to evade the immune system leading to a chronic inflammatory state $[13,14]$.

In addition to chlamydial persistent forms, the chronic inflammatory state and, hence, tissue damage might also be correlated to a dysregulated inflammasome activation, a widely studied innate immune pathway in other bacterial infections [15]. Indeed, regulated inflammasome activation usually leads to the induction of proinflammatory signaling networks with consequent bacterial infection control [16]. Inflammasomes are macromolecular protein complexes consisting mainly of an NLR family member, an adaptor apoptosis-associated speck-like protein containing a caspase recruitment domain (ASC) and caspase-1 [16]. The latter, once activated in response to infection, mediates the production of potent inflammatory cytokines like interleukin (IL)-1 $\beta$ and IL-18, and leads to an inflammatory form of cell death [16]. The activation of the NLRP3 inflammasome has also been involved in the pathogenesis of synovial tissue damage [17]. Specifically, the caspase- 1 mediated production of IL-1 $\beta$ was shown to exacerbate the prodegradative mechanisms responsible for cartilage breakdown [18]. Other inflammasome related proinflammatory cytokines, like IL-18, have also been demonstrated to contribute to synovial inflammation [19].

Caspase- 1 activated IL-18 is also a potent inducer of IL- $1 \beta$, IL- 8 , and interferon (IFN)$\gamma[20,21]$, which has been demonstrated to play a key role in the clearance and protection against $C$. trachomatis by modulating a plethora of host cell signaling pathways $[22,23]$. Interestingly, in our recent study, the anti-chlamydial activity of IFN- $\gamma$ has also been demonstrated in primary human synovial fibroblasts through the modulation of the hostcell innate immune responses, as evidenced by an increased expression of TLR2, 3 and 4, and IFN-related pathways, including GAS, STING, IRF9, ISG56, and GBP1 [11].

Given that IFN- $\gamma$ and inflammasomes are two important mediators of host immune response against chlamydial infection, herein we investigated, for the first time, the interaction between IFN-y and inflammasome in an in vitro model of $C$. trachomatis infected human synovial fibroblasts. In particular, the expression of caspase- 1 and the downstream inflammatory cytokines IL-1 $\beta$, IL-8, IL-18 and IL-6 were determined.

\section{Materials and Methods}

\subsection{Cell Culture and Culture Conditions}

Primary human fibroblast-like synoviocytes (HFLS, 408K-o5a, Cell Applications Inc., San Diego, CA, USA) were seeded in $25 \mathrm{~cm}^{2}$ cell-culture flasks (angled neck, tissue-culture treated, Corning, NY, USA) and grown in Dulbecco's Modified Eagle Medium (DMEM, with $4.5 \mathrm{~g} / \mathrm{L}$ glucose, L-glutamine and sodium pyruvate, Corning, NY, USA) supplemented with $15 \%$ v/v fetal bovine serum (FBS, South American Origin, Corning, NY, USA), penicillin $(100 \mathrm{U} / \mathrm{mL})$ and streptomycin $(100 \mu \mathrm{g} / \mathrm{mL})$ (penicillin-streptomycin Solution, 50X, Corning, NY, USA) at $37{ }^{\circ} \mathrm{C}$ in humidified atmosphere with $5 \% \mathrm{CO}_{2}$. At $85 \%$ confluency level, cells were passaged via 2 min trypsinization $(0.05 \%$ trypsin in $0.53 \mathrm{mM}$ EDTA, $1 \mathrm{X}$, Corning, NY, USA), and all experiments were performed using cells that were passaged for at least 4 or 5 times.

McCoy cells (ECACC, Public Health England, catalogue number 90010305, Porton Down, Salisbury, UK), were cultured in DMEM supplemented with $10 \% v / v$ FBS, at $37^{\circ} \mathrm{C}$ in humidified atmosphere with $5 \% \mathrm{CO}_{2}$. 


\subsection{Propagation and Titration of $C$. trachomatis}

C. trachomatis serovar D strain UW3 (VR-885, ATCC, Manassas, VA, USA) was propagated in McCoy cells, as previously described [6]. Briefly, confluent cell monolayers, grown on $25 \mathrm{~cm}^{2}$ cell-culture flasks, were infected with a stock solution containing chlamydial EBs by centrifugation at $754 \times g$ for $30 \mathrm{~min}$ and then harvested by scraping after 36 to $40 \mathrm{~h}$ post-infection (h.p.i.). The resulting suspension was vortexed with sterile glass beads for $1 \mathrm{~min}$ and, after cell-debris removal by centrifugation at $250 \times \mathrm{g}$ for $10 \mathrm{~min}$, the supernatant, containing chlamydial EBs, was added to equal volume of $4 \times$ sucrose phosphate (4SP) buffer ( $0.4 \mathrm{M}$ sucrose and $16 \mathrm{mM} \mathrm{Na}_{2} \mathrm{HPO}_{4}$ adjusted to $\mathrm{pH}$ 7.1, and filter sterilized), and stored at $-80^{\circ} \mathrm{C}$.

For the titration of $C$. trachomatis, confluent cell monolayers, grown on 24-well cellculture plates, were infected with 10-fold serial dilutions of chlamydial EB stock by centrifugation and then incubated for $48 \mathrm{~h}$ at $37^{\circ} \mathrm{C}$, fixed with $96 \%$ ice-cold methanol and stained with fluorescein isothiocyanate-conjugated monoclonal antibody anti-C. trachomatis outer membrane protein (Chlamydia Cel kit, Cellabs, Sydney, AU; catalog number KC1), as previously described [24]. The total number of $C$. trachomatis inclusion forming units (IFUs) was enumerated by counting all microscope fields using a fluorescence microscope (DM4000, Leica Microsystems GmbH, Wetzlar, Germany).

\subsection{Infection of Human Synovial Cells with C. trachomatis and Pretreatment with IFN- $\gamma$}

Human synovial cells were grown on 24-well cell-culture plates or on $25 \mathrm{~cm}^{2}$ cellculture flasks. Upon confluence, cell monolayers were either pre-incubated with IFN- $\gamma$ at a concentration of $10^{3} \mathrm{U} / \mathrm{mL}$ in DMEM with $15 \%$ FBS, or pre-incubated in DMEM with $15 \%$ FBS alone, at $37^{\circ} \mathrm{C}$ in humidified atmosphere with $5 \% \mathrm{CO}_{2}$, as previously described [11]. After $24 \mathrm{~h}$, cell monolayers were washed with PBS, infected with $C$. trachomatis at a multiplicity of infection (MOI) of 1.0 as above described, and then incubated at $37^{\circ} \mathrm{C}$ for 6,18 , 24 and 36 h.p.i. At each time-point, the cell monolayers on 24-well cell-culture plates were either fixed with ice-cold methanol and stained as above described, for the determination of $C$. trachomatis infection efficiency via fluorescence microscopy or harvested and stored at $-80^{\circ} \mathrm{C}$ for the infectivity assay. Infected cell monolayers on $25 \mathrm{~cm}^{2}$ cell-culture flasks were harvested by scraping, pelleted by centrifugation at $10,000 \times \mathrm{g}$ for $10 \mathrm{~min}$, and stored at $-80{ }^{\circ} \mathrm{C}$ for mRNA extraction and real-time RT-PCR assay. Cell supernatants were also aliquoted and stored at $-80^{\circ} \mathrm{C}$ for the determination of protein levels via ELISA.

\subsection{Efficiency of C. trachomatis Infection in Human Synovial and McCoy Cells}

The efficiency of $C$. trachomatis infection in human synovial and McCoy cells was investigated by infecting confluent cell monolayers grown on coverslips in 24-well cellculture plates with $C$. trachomatis at a MOI of 1.0 as above described. After $36 \mathrm{~h}$ incubation, the number of chlamydial IFUs was enumerated by counting all microscope fields via a fluorescence microscope.

\subsection{Growth Curve of C. trachomatis in Human Synovial Cells}

The growth curve of $C$. trachomatis in human synovial cells was performed infecting confluent cell monolayers, grown on 24-well cell-culture plates, with $C$. trachomatis at a MOI of 1.0. At 6, 18, 24 and 36 h.p.i., infected cells were harvested and stored at $-80^{\circ} \mathrm{C}$. To assess the infectivity at each time-point, $C$. trachomatis EBs suspensions were titrated as above described.

\subsection{TaqMan-Based Real-Time RT-PCR Assay}

Quantitative real-time PCR for caspase-1, IL-1 $\beta$, IL-8, IL-18 and IL-6 was carried out with the LightCycler 480 instrument (Roche, Basel, Switzerland). Briefly, at 6, 18 and 24 h.p.i., total RNA was extracted using the RNeasy Plus Universal Tissue Mini Kit (Invitrogen, Carlsbad, CA, USA). RNA extracts were reverse transcribed using the High-Capacity cDNA Reverse Transcription Kit (Applied Biosystems, Woburn, MA, USA), according to 
the manufacturer's instruction. Primers and probes for each gene were added to the Probes Master Mix (Roche, Basel, Switzerland) at 500 and $250 \mathrm{nM}$, respectively, in a final volume of $20 \mu \mathrm{L}$. The housekeeping gene $\beta$-glucuronidase (GUS) was used as an internal control. GUS was selected as a good candidate for the housekeeping gene in our experimental setting, because it was constantly expressed in synovial cells after $C$. trachomatis or IFN stimulation. Gene expression values were calculated by the comparative $2-\Delta \mathrm{Ct}$ methods. The primers and probe were assayed on demand and were purchased from Integrated DNA Technologies (IDT), Clear Creek, IA, USA. The list of primers and probes is as follows: IFNAR1: Hs.PT.58.20048943; IFNAR2: Hs.PT.58.1621113; IFNGR1: Hs.PT.58.20918191; IFNGR2: Hs.PT.58.38961914; IL-1ß: Hs.PT.58.1518186; caspasi1: Hs.PT.59a.22997425.g; IL-6: Hs.PT.58.40226675; IL-18: Hs.PT.58.25675872; IL-8: Hs.PT.58.39926886.g.

\subsection{ELISA Assay}

At 6, 18 and 24 h.p.i., the supernatants collected from infected human synovial cells were analyzed for IL-1 $\beta$, IL-8, IL-18 and IL-6 using the specific FineTest ELISA kits (Wuhan Fine Biotech Co., Ltd., Wuhan, China; catalog numbers EH0185, EH0205, EH0011 and EH0201, respectively), according to the manufacturer's instructions. The detection limit for each cytokine is as follows: Il- $1 \beta, 2.344 \mathrm{pg} / \mathrm{mL} ; \mathrm{Il}-8,18.75 \mathrm{pg} / \mathrm{mL} ; \mathrm{Il}-18,9.375 \mathrm{pg} / \mathrm{mL}$ and IL-6, $2.813 \mathrm{pg} / \mathrm{mL}$.

\subsection{Caspase Inhibition in Human Synovial Cells}

Confluent synovial monolayers, grown on coverslips in 24-well cell-culture plates, were either pre-incubated with IFN- $\gamma$ at a concentration of $10^{3} \mathrm{U} / \mathrm{mL}$, or in DMEM with $15 \%$ FBS alone, at $37{ }^{\circ} \mathrm{C}$ in humidified atmosphere with $5 \% \mathrm{CO}_{2}$. After $24 \mathrm{~h}$ incubation, cell monolayers were infected with $C$. trachomatis at a MOI of 1.0 as above described. At 6 h.p.i., the pan-caspase inhibitor Z-VAD-FMK (Enzo Life Sciences, Inc., Farmingdale, NY, USA) was added to the infected cell monolayers at a concentration of $20 \mu \mathrm{M}$. At 36 h.p.i., cells were fixed with ice-cold methanol and stained as above described, and the number of chlamydial IFUs was enumerated by counting all microscope fields via a fluorescence microscope. At the same time, the cytotoxic effect of the pan-caspase inhibitor on the human synovial cell line at the concentration of $20 \mu \mathrm{M}$ was tested via MTT assay and viable cell count, as previously described [25].

\subsection{Statistical Analysis}

All values were expressed as mean \pm standard deviation (SD) of three replicates from three independent experiments. After assessing data normality via Shapiro-Wilk test, the comparison of means was either performed by using a two-tailed student $t$-test for independent samples or a Mann-Whitney $U$ test for non-parametric data distributions. Two-way ANOVA was performed for the analysis of variance. All statistical calculations were performed in Microsoft Excel software (version 2110), by using the Real Statistics Resource Pack (release 7.9.1, https:/ / www.real-statistics.com, accessed on 1 July 2021). A value of $p<0.05$ was considered statistically significant.

\section{Results}

3.1. C. trachomatis Productively Infects Primary Human Synovial Cells

C. trachomatis showed the ability to productively infect the primary human synovial cells, as shown by the presence of the typical green-fluorescent inclusions after staining with FITC-conjugated mouse monoclonal antibody anti-chlamydial MOMP (Figure 1A). However, the infection rate was significantly lower than that in McCoy cells, the gold standard for Chlamydia laboratory culture, with a synovial to McCoy cells ratio of 0.013 $(p=0.00026$, Figure 1B). Chlamydial inclusion morphology was also different in synovial as compared to McCoy cells, where inclusions had similar size and shapes; by contrast, in synovial cells, inclusions presented a heterogeneous morphology, as shown in Figure S1. 
The presence of $C$. trachomatis inclusions in synovial cells was further confirmed via staining with anti-C. trachomatis LPS monoclonal antibody (Figure S2).

A
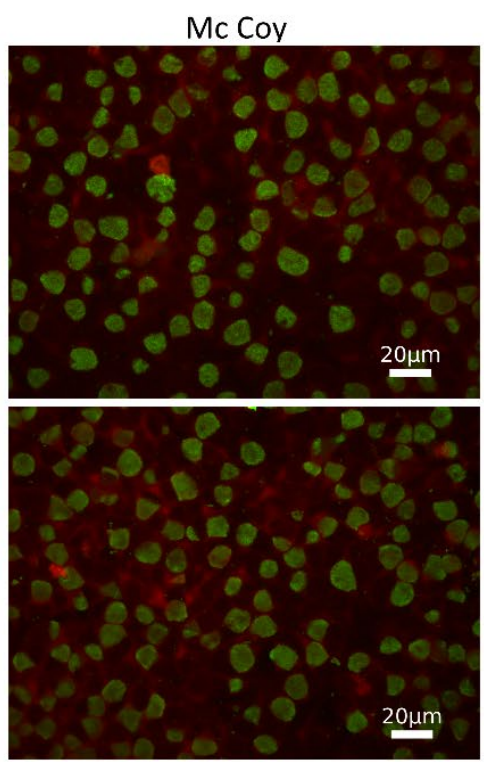

Synovial cells

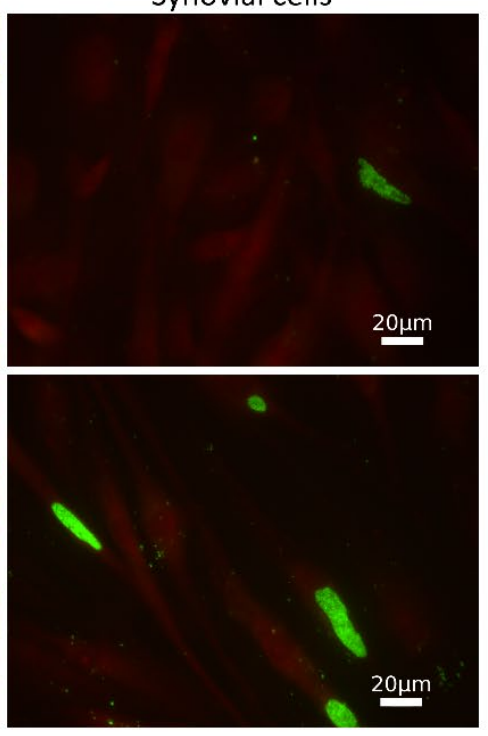

B

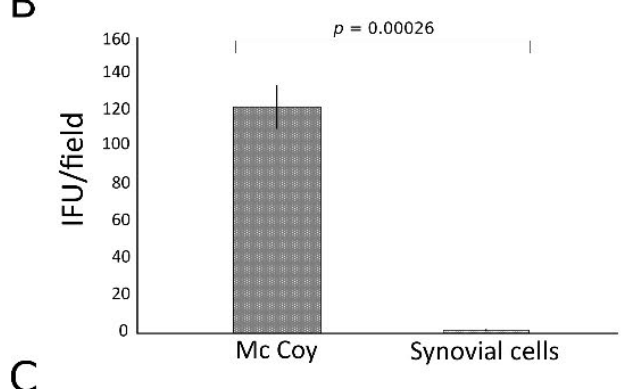

C

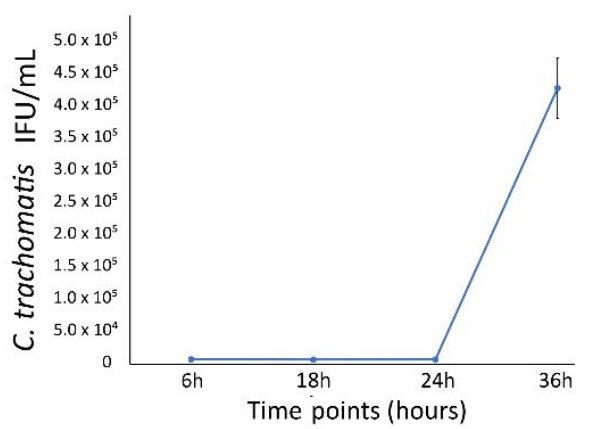

Figure 1. Growth characteristics of C. trachomatis in synovial cells. Synovial and McCoy cells were infected with C. trachomatis (MOI 1.0), and, at 36 h.p.i, chlamydial inclusions were counted by immunofluorescence staining; (A) representative micrographs of C. trachomatis inclusions in synovial and McCoy cells; (B) C. trachomatis infection efficiency in human synovial and McCoy cells. (C) Kinetics of replication of C. trachomatis in synovial cells. Infected synovial cells (MOI 1.0) were harvested at 6, 18, 24 and 36 h.p.i. and inoculated onto McCoy cells. After 36 h.p.i., the recoverable viable C. trachomatis bacteria were quantitated and expressed as IFU $/ \mathrm{mL}$.

To characterize the growth phenotype of $C$. trachomatis in primary human synovial cells, we sampled multiple time points across the duration of the chlamydial developmental cycle for determining chlamydial EB infectivity. The infectivity growth curve showed a relatively long eclipse period for $C$. trachomatis in human synovial cells, with infectious EBs appearing at $36 \mathrm{~h}$ postinfection (Figure $1 \mathrm{C}$ ). No persistent forms have been identified in the experimental conditions studied, as evidenced by no reduction of inclusion via infectivity assay (Figure 1C).

3.2. C. trachomatis Infection of Human Synovial Cells Upregulates the Expression of IL-1 $\beta$ and Caspase-1 Genes Involved in the Host-Cell Inflammasome Pathway

The mRNA expression levels of caspase- 1 and the inflammatory mediators IL-1 $\beta$, IL-6, IL-18, IL-8 are reported in Figure 2.

The analysis of variance of inflammatory mediator levels in human synovial cells following C. trachomatis infection as compared to uninfected cells, showed statistically significant differences related to the type of inflammatory mediator (IL-1 $\beta$, IL-6, IL-18, IL-8 and caspase-1) or the time postinfection $(6,18$ and 24 h.p.i.) as well as the interaction between these two factors $\left(p=2.69 \times 10^{-21}, p=1.73 \times 10^{-14}\right.$ and $p=8.70 \times 10^{-17}$, respectively).

Particularly, $C$. trachomatis infection of human synovial cells led to a more than 100-times increase in the mRNA expression levels of IL-1 $\beta$, IL- 6 and caspase- 1 genes at 18 and 24 h.p.i. $(p<0.05)$, while no increase was observed for the inflammatory mediators IL-8 and IL-18 (Figure 2). 


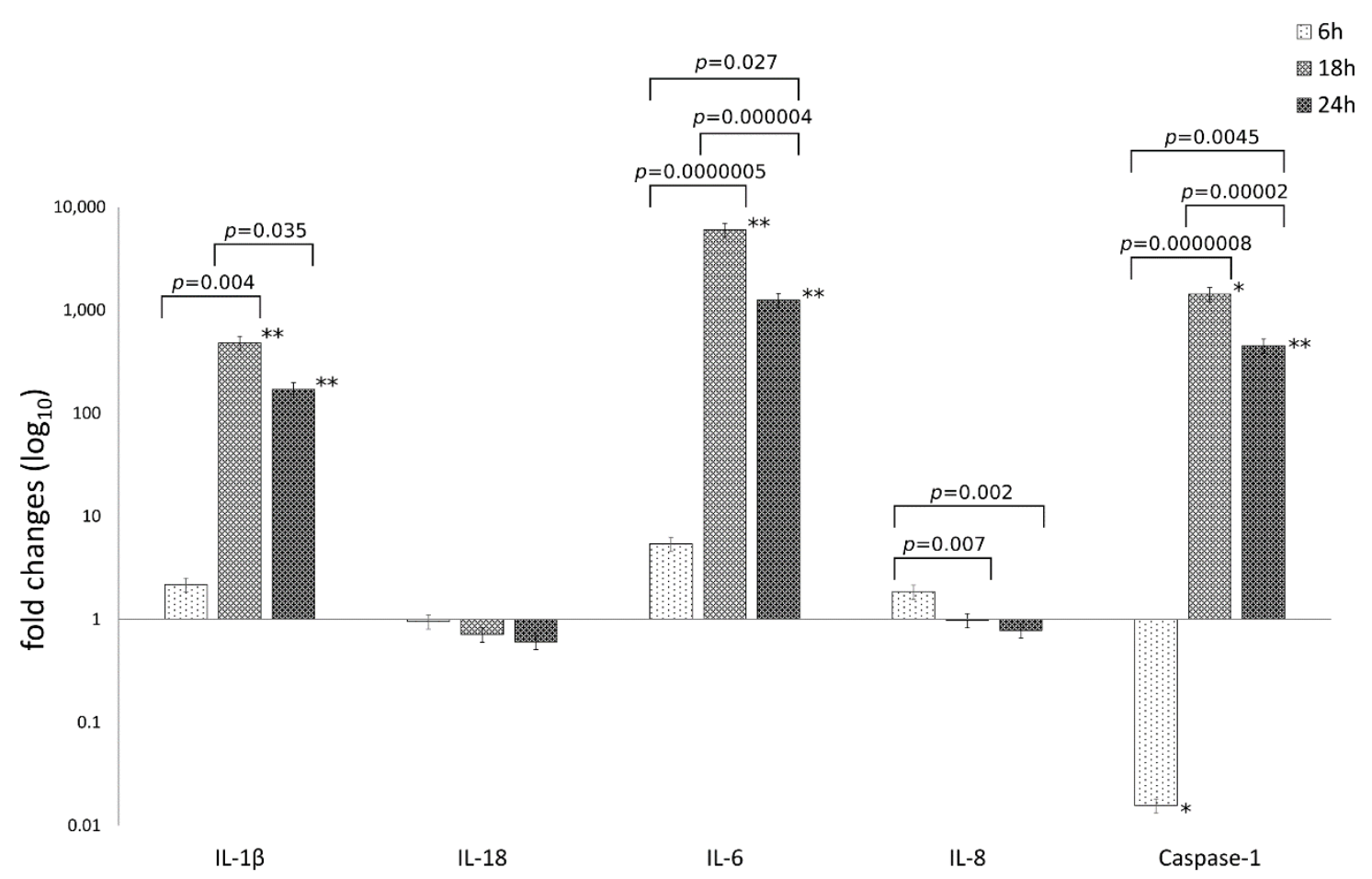

Figure 2. Relative mRNA expression of IL-1 $\beta$, IL-18, IL-6, IL-8 and caspase-1 following C. trachomatis infection of synovial cells. Results are expressed as fold changes, as compared to uninfected cells, of mRNA expression levels at 6, 18 and 24 h.p.i., via reverse transcription real-time PCR. *,$p<0.05 ;{ }^{* *}, p<0.01$.

Interestingly, IL-1 $\beta$, IL-6 and caspase-1 mRNA levels increased after 6 h.p.i. with a peak expression at 18 h.p.i. $(p<0.00001)$ and consistently high levels at 24 h.p.i.; IL-6 showed the highest levels as compared to the other inflammatory mediators $(p<0.01$, Figure 2$)$.

3.3. IFN $\gamma$ Pretreatment of Human Synovial Cells Modulates the Host Cell Response against C. trachomatis Infection

The mRNA expression levels of caspase- 1 and the inflammatory mediators IL-1 $\beta$, IL-18, IL-6, IL-8, in the presence or absence of IFN- $\gamma$ pretreatment of human synovial cells, are reported in Figure 3.

The analysis of variance between IL-1 $\beta$, IL-18, IL-6, IL-8 and caspase- 1 levels, showed statistically significant differences related to the infection conditions or the time after infection (6,18 and 24 h.p.i.) as well as the interaction between these two factors (Table S1).

In $C$. trachomatis-infected synovial cells, the pretreatment with IFN- $\gamma$ significantly decreased the mRNA expression levels of IL- 6 and Caspase- 1 genes at later time points during the chlamydial developmental cycle (18 and 24 h.p.i. for caspase- 1 and 24 h.p.i. for IL-6, $p<0.000001$ and $p<0.05$, respectively), as evidenced by Figure 3. Conversely, the pretreatment with IFN- $\gamma$ significantly increased the expression of IL-1 $\beta$ and IL- 8 genes at both 18 and 24 h.p.i. $(p<0.01$, Figure 3). IL-18 showed only a modest increase at 6 h.p.i. $(p<0.05$, Figure 3). 
$\mathrm{IL}-1 \beta$

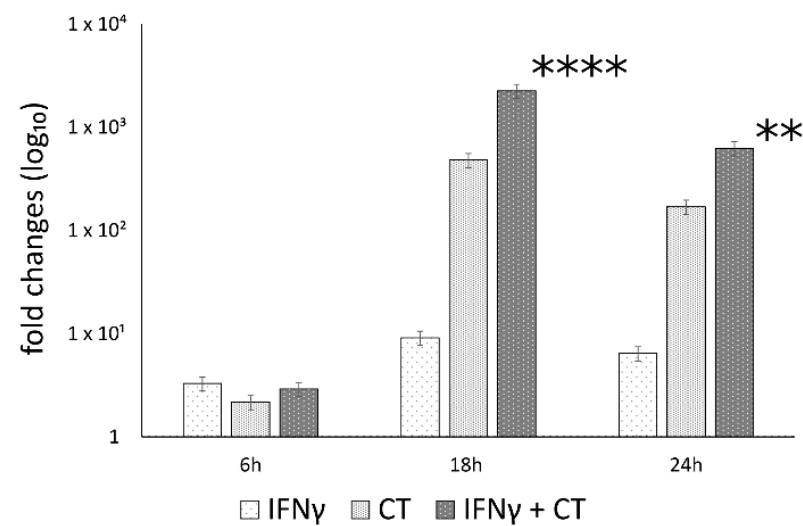

IL-8

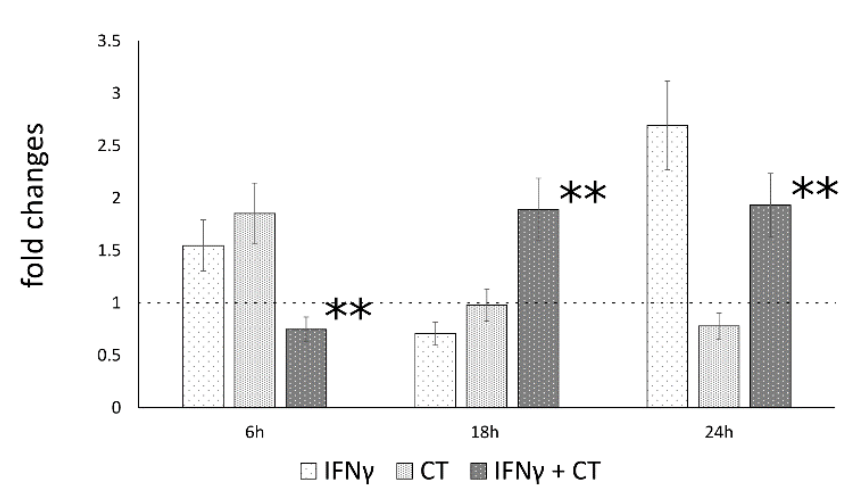

Caspase-1

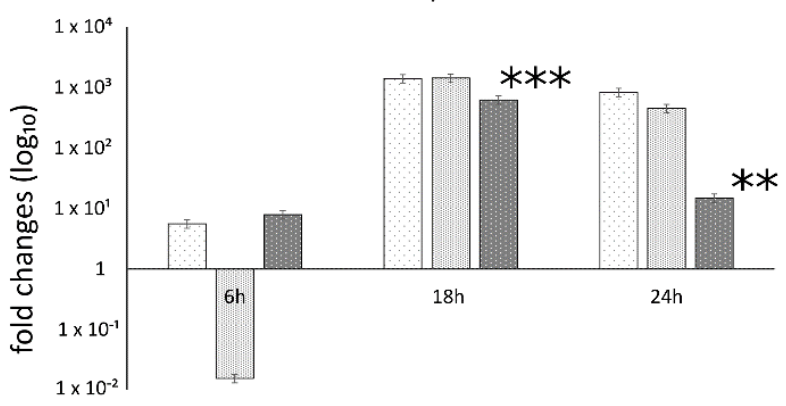

$\square$ IFNY $\square$ CT $\quad$ IFNY + CT
IL-6

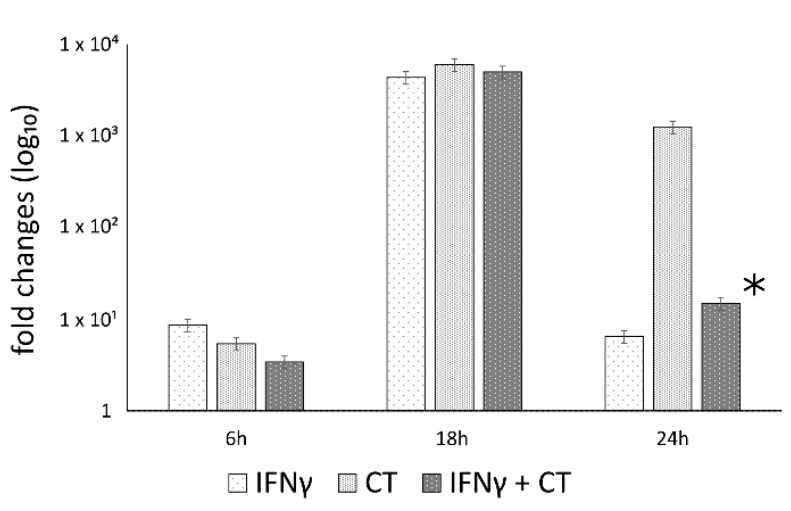

IL-18

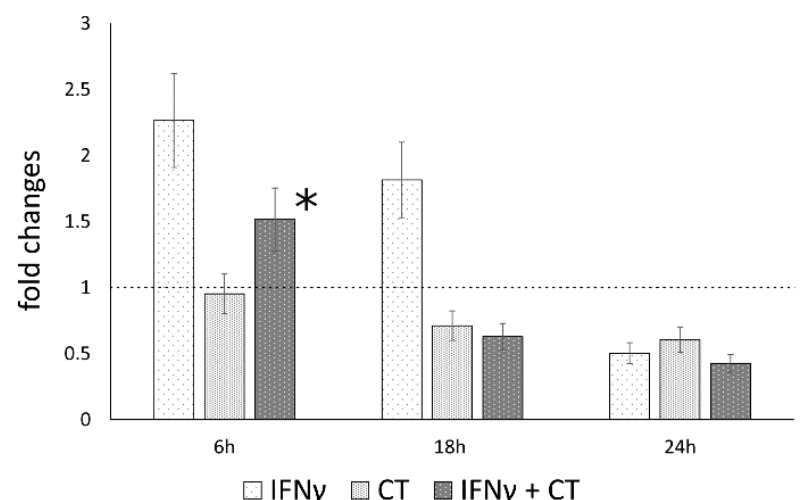

Figure 3. IFN- $\gamma$ effects on the relative mRNA expression of IL-1 $\beta$, IL-18, IL-6, IL-8 and caspase-1. C. trachomatis infected synovial cells pretreated with IFN- $\gamma$ as well as untreated or uninfected cells were assayed via reverse transcription real-time PCR. ${ }^{*} p<0.05,{ }^{* *} p<0.01,{ }^{* * *} p<0.0001$ and ${ }^{* * *} p<0.00001$ vs. C. trachomatis infected cells.

\subsection{IFN- $\gamma$ Pretreatment in C. trachomatis Infected Human Synovial Cells Modulates IFN Receptor Gene Expression}

Following the observation that IFN- $\gamma$ pretreatment of chlamydia-infected human synovial cells modulated the gene expression of IL- $1 \beta$ and caspase- 1 , we explored whether IFN $\gamma$ may also regulate the expression of IFN-I and IFN-II receptor genes, namely the receptor chains IFN $\alpha \mathrm{R} 1$ and IFN $\alpha \mathrm{R} 2$, as well as IFN $\gamma \mathrm{R} 1$ and IFN $\gamma \mathrm{R} 2$, potentially exerting positive feedback on its own signaling pathways.

Our results showed that $C$. trachomatis infection induced an overall increase in the mRNA levels of type-I IFN receptor at all time points (6, 18 and 24 h.p.i.), with the highest mRNA expression at 18 h.p.i. for the IFN $\alpha$ R1 and IFN $\alpha$ R2 $(p<0.001)$ (Figure 4$)$. Conversely, 
the mRNA expression levels of type-I and type-II IFN receptor genes significantly decreased after IFN $\gamma$ pretreatment of chlamydia-infected human synovial cells at either 18 h.p.i. (IFN $\alpha$ R1 and IFN $\gamma$ R2, $p<0.001$ ) or 24 h.p.i. (IFN $\alpha$ R1 and IFN $\alpha$ R2, as well as IFN $\gamma$ R1 and IFN $\gamma \mathrm{R} 2, p<0.01, p<0.05, p<0.000001$ and $p<0.000001$, respectively, Figure 4 ).

IFNaR1

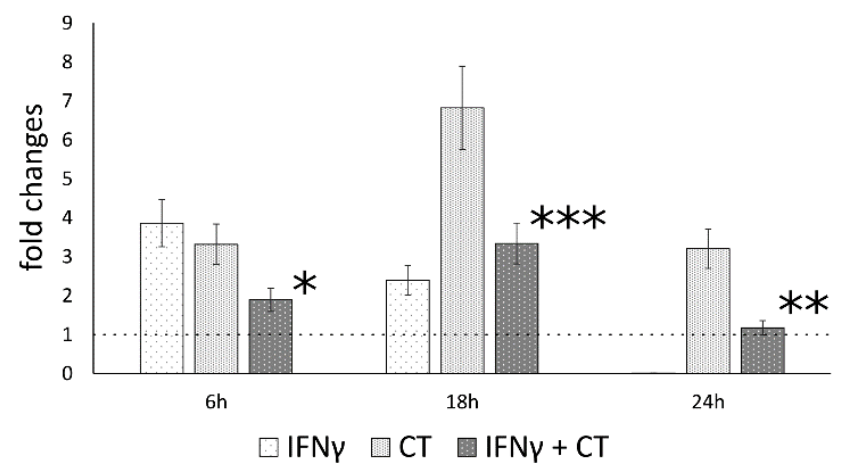

IFN $p R 1$

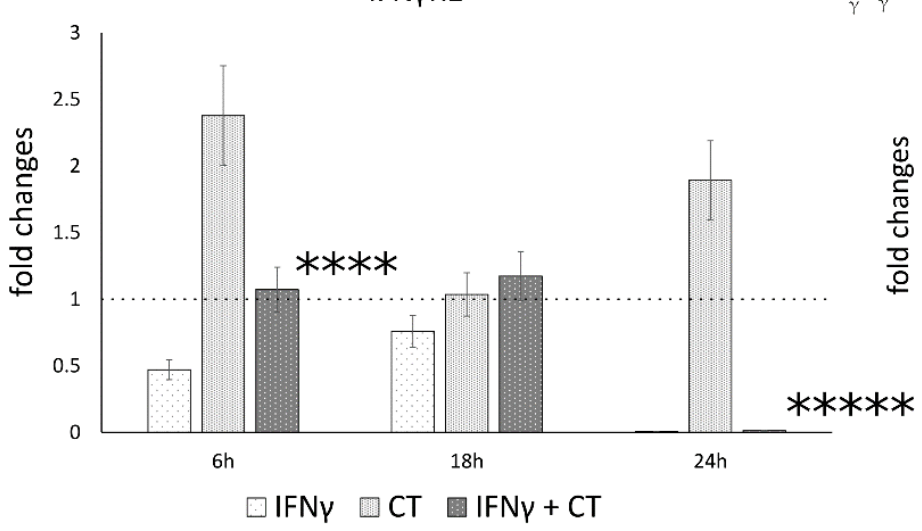

IFNaR2

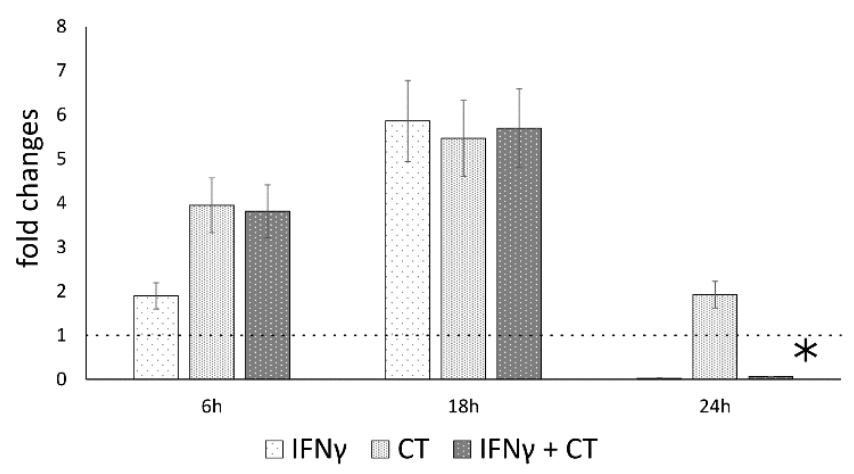

IFNYR2

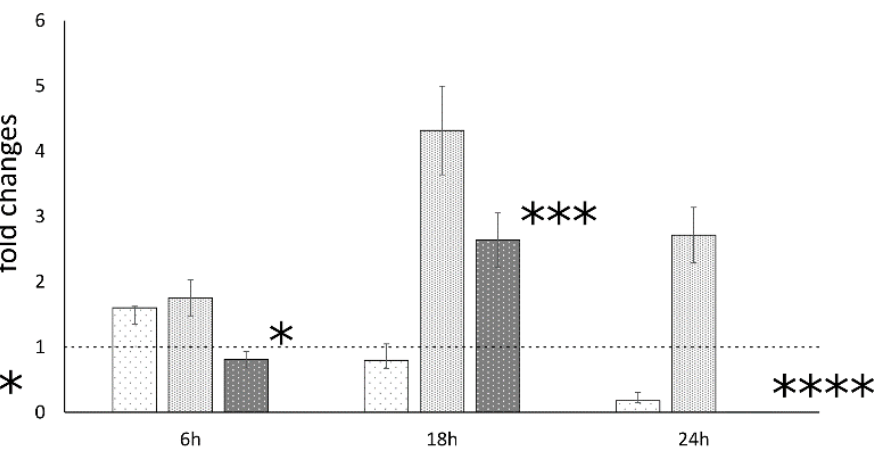

Figure 4. IFN- $\gamma$ effects on the relative mRNA expression of IFN $\alpha R 1$, IFN $\alpha R 2$, IFN $\gamma$ R1 and IFN $\gamma$ R2 receptor chains. C. trachomatis infected synovial cells pretreated with IFN $\gamma$ as well as untreated or uninfected cells were assayed via reverse transcription rt-PCR. ${ }^{*} p<0.05,{ }^{* *} p<0.01,{ }^{* * *} p<0.001,{ }^{* * * *} p<0.0001$ and ${ }^{* * * *} p<0.00001$ vs. C. trachomatis infected cells.

\subsection{IFN- $\gamma$ Pretreatment in C. trachomatis-Infected Human Synovial Cells Increases Inflammatory Cytokine Production}

Since an increase in caspase-1, IL-1 $\beta$ and IL-6 gene expression levels was observed following C. trachomatis infection of human synovial cells, we, then, proceeded to analyze their related protein levels.

In contrast to the mRNA expression data, no statistically significant increase in the related protein levels of the cytokines IL-1 $\beta$, IL-6, IL-18 and IL-8 was observed following C. trachomatis infection of human synovial cells, as evidenced in Figure 5.

On a different note, IFN- $\gamma$ pretreatment led to a statistically significant increase in the protein levels of IL-1 $\beta$, IL-6 and IL- 8 at 6 or 18 h.p.i., as shown in Figure 5, mirroring the mRNA expression data, while no increase was observed for IL-18. 
IL-1 $\beta$

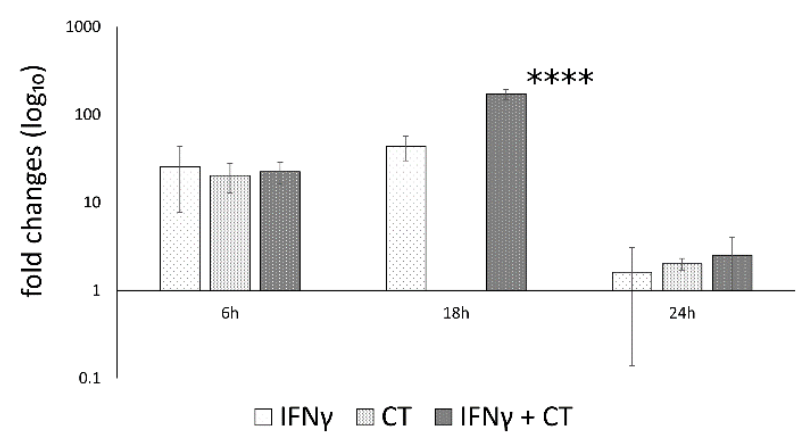

IL-8

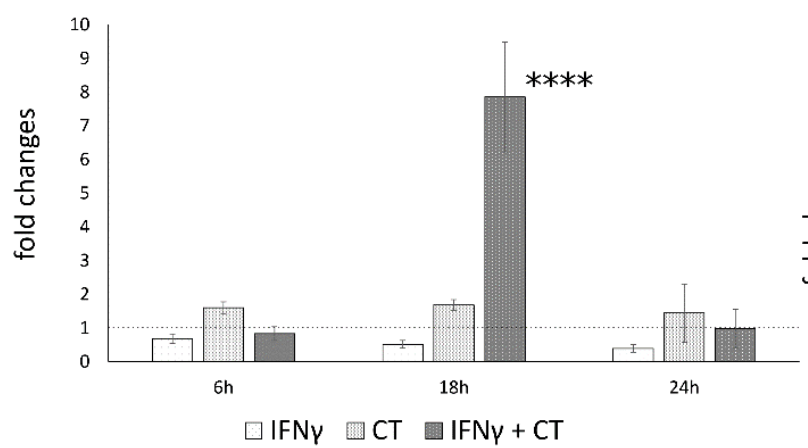

IL-6

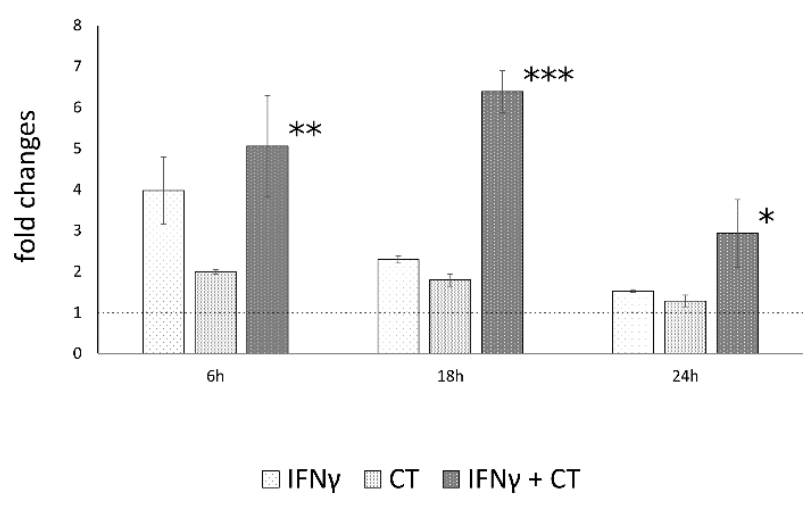

IL-18

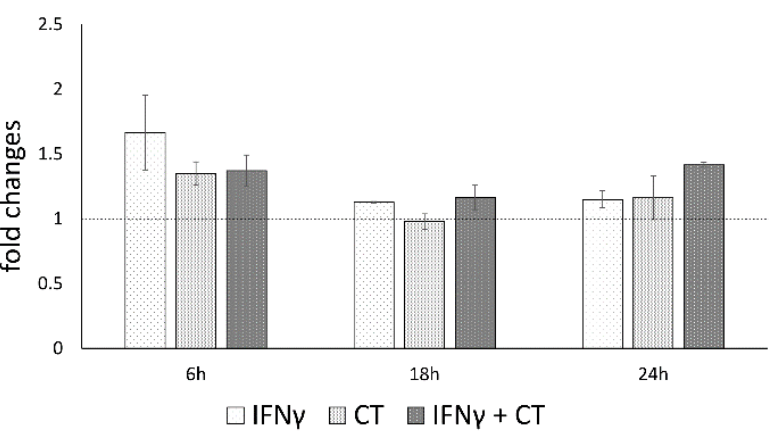

Figure 5. IFN- $\gamma$ effects on the protein levels of IL-1 $\beta$, IL-6, IL-8 and IL-18. C. trachomatis-infected synovial cells pretreated with IFN- $\gamma$ as well as untreated or uninfected cells were assayed via ELISA. ${ }^{*} p<0.05,{ }^{* *} p<0.001,{ }^{* * *} p<0.0001$ and **** $p<0.000001$ vs. C. trachomatis infected cells.

\subsection{The Anti-Chlamydial Activity of IFN- $\gamma$ Is Correlated to the Inhibition of Caspases}

To investigate whether inflammasome related caspases played a role in C. trachomatis replication and was involved in the anti-chlamydial activity of IFN- $\gamma$, chlamydia infected human synovial cells were exposed to the pan-caspase inhibitor.

As shown in Figure 6, the number of C. trachomatis IFUs significantly decreased after the treatment with the pan-caspase inhibitor $(p<0.05)$. Interestingly, the reduction of chlamydia replication following the inhibition of caspases was comparable to that caused by IFN- $\gamma$ pretreatment of synovial cells $(-60.8 \%$ vs. $-54.4 \%$, respectively, $p=\mathrm{NS})$. Lastly, the anti-chlamydial activity of IFN- $\gamma$ was significantly potentiated by the inhibition of caspases $(p<0.0001)$.

Of note, the treatment with pan-caspase inhibitor had no cytotoxic effect on the synovial cells, as evidenced by MTT assay and viable cell count (Figure S3), showing, hence, a specific activity toward C. trachomatis. 


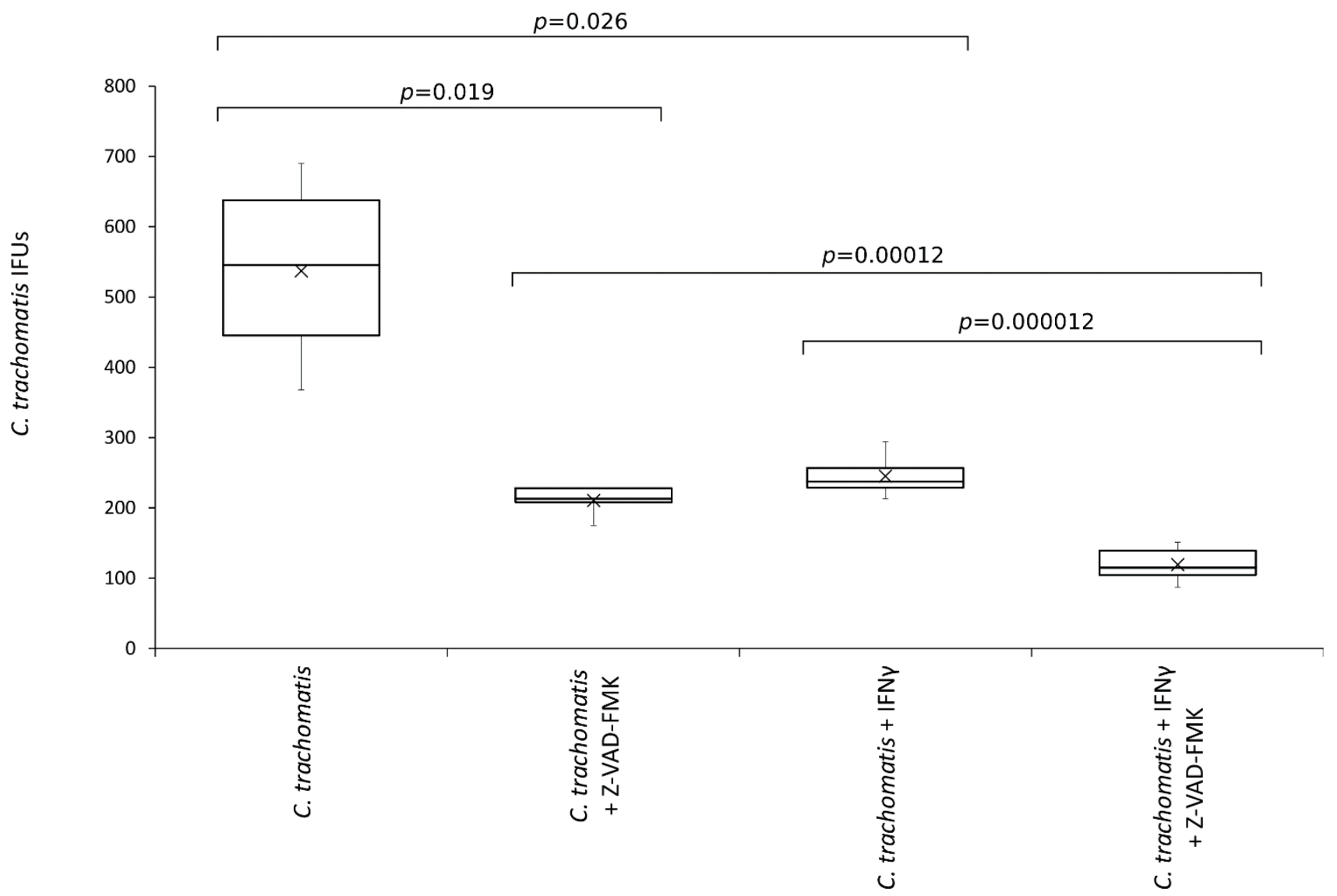

Figure 6. Effects of pan-caspase inhibitor on C. trachomatis IFUs. IFN- $\gamma$ pretreated and untreated synovial cell monolayers were infected with $C$. trachomatis at a MOI of 1.0 and exposed to the pan-caspase inhibitor Z-VAD-FMK $(20 \mu \mathrm{M})$ at 6 h.p.i. The number of chlamydial IFUs was counted by fluorescence microscopy.

\section{Discussion}

The main results of our study show that: (i) C. trachomatis may affect the canonical inflammasome pathway, productively infecting primary human synovial cells; (ii) IFN- $\gamma$ inhibits C. trachomatis replication by partly acting on the host-cell immune response, most likely via the regulation of the inflammasome network.

In our chlamydial infection model based on primary human synovial cells, we demonstrated that $C$. trachomatis infection might induce the canonical inflammasome pathway promoting caspase- 1 gene expression.

The activation of the inflammasome pathway is key to limiting infection by several invading bacterial pathogens, but it requires tight regulation in order to prevent inflammation and immunopathology, since it typically leads to the production of the most potent proinflammatory cytokines (IL-1 $\beta$ and IL-18) and the subsequent induction of inflammatory cell death [16].

In our study, unconventionally, inflammasome-mediated caspase-1 gene expression seemed to play an important role in intracellular growth of $C$. trachomatis in synovial cells, as suggested by caspase inhibition. This leads to the hypothesis that Chlamydia employed an evasion strategy against the host cell response, as also hinted at by the absent production of IL-1 $\beta$ and IL-18, observed in our study. In support of the involvement of caspase- 1 in the replication phase of $C$. trachomatis, a significant reduction in the chlamydial inclusion number was observed after the treatment with a pan-caspase inhibitor. Consistent with this observation, blocking caspase- 1 with an inhibitor in fibroblasts makes them less susceptible to C. trachomatis infection [26]. Similarly, in cervical epithelial 
cells, inflammasome-dependent caspase- 1 activation was demonstrated to contribute to chlamydial growth and did not lead to IL-1 $\beta$ production [27].

By contrast, in other cell types, such as monocyte-macrophages and trophoblasts, the activation of inflammasome after $C$. trachomatis infection was demonstrated to mediate IL-1 $\beta$ production in a process requiring caspase- 1 activation $[9,28-31]$.

Although the basis for caspase- 1 stimulation of chlamydial infection is not well defined [32] and remains poorly characterized in our human synovial cell model, we found that exposure of $C$. trachomatis-infected cells to IFN- $\gamma$ may modulate the canonical inflammasome pathway by reducing the gene expression of caspase- 1 . These findings support our previous work on anti C. trachomatis activity of IFN- $\gamma$ and yield novel insights into mechanisms by which this cytokine could interfere with its replication [11]. Previous studies have shown that caspase- 1 can be upregulated by IFN- $\gamma$ in distinct cell lines [33-35]. However, it has been also proposed that IFN-inducible proteins could act also as negative regulators for inflammasome activation [36], underlining the increasing complexity of this regulatory network. In this regard, IFN- $\gamma$ not only inhibits $C$. trachomatis metabolic growth favoring the depletion of tryptophan [37], but also interferes with several host immune pathways [38], like caspase-1 downregulation, as evidenced by our findings. Indeed, IFN- $\gamma$ knockout mice exhibited Th2-associated delayed-type hypersensitivity and the inflammatory cells failed to localize and control the chlamydial infection, indicating that IFN- $\gamma$ exerts beneficial effects for the host's defense against Chlamydia infection [39]. In this study, we further demonstrated that IFN- $\gamma$ led to increased inflammation, as compared to $C$. trachomatis infection alone, characterized by IL-1 $\beta$, IL- 8 and IL- 6 . These proinflammatory cytokines are typically associated to cell damage [40], although it remains unknown whether this IFN- $\gamma$-mediated immunological effect on human synovial cells is helpful or harmful during $C$. trachomatis infection. However, both IL-1 $\beta$ and IL- 8 have been shown to actively participate with other cytokines in the systemic inflammatory response during C. trachomatis infection [41,42]. Moreover, the expression of these cytokines can be tightly regulated by IFN- $\gamma$ through several positive and negative feedback loops [43,44], suggesting that this cytokine drives other inflammatory pathways, partly contrasting the potential evasion of the host-cell immune response following Chlamydia infection. We also found a large discrepancy between mRNA transcript levels (Figure 2) and protein expression levels (Figure 5), especially IL-1 $\beta$ and IL- 6 . The lack of correlation of the cytokine mRNA to protein levels of IL- $1 \mathrm{~b}$ and IL-6 was not unexpected as regulation of the actual protein level is likely more complex than a direct relationship to the amount of mRNA and the rate of translation and thus the amount of mRNA does not necessarily directly correlate with the level of protein expressed. Indeed, evidence in the literature indicates that multiple post-transcriptional or translational mechanisms are involved in regulating the synthesis of these two cytokines [45-49]. In this regard, it is also known that cytokine mRNA decay is tightly regulated at the post-transcriptional level through cis- or trans-acting elements [50].

A limitation of our study is that transcript levels are not sufficient to predict caspase-1 activation levels. Caspase- 1 activation occurs via proteolytic cleavage of pro-caspase molecules, leading to relatively short-lived protein products that can be detected in model systems by Western blot analysis. However, the data generated by this in vitro analysis may not reflect the actual in vivo effects caused by C. trachomatis infection and/or IFN$\gamma$ response on caspase- 1 activation. Alternatively, detection of the correct fragments of unseparated and cleaved IL-1b and/or IL-18 might show caspase-1 activity. We addressed the question of caspase- 1 involvement in the synovial cell model of $C$. trachomatis infection and in vitro regulation by IFN- $\gamma$ through testing a potentially longer inflammation-related signature, the transcriptional regulation of caspase- 1 mRNA. However, these results advise caution in overinterpreting the significance of the changes found in our in vitro model of C. trachomatis-infected primary human synovial cells.

Of note, we found that IFN- $\gamma$ decreased the expression of the type-II IFN receptors, whereas C. trachomatis infection induced an overall increase in the expression of all the IFN receptor chains. The latter might be used to render these cells more resistant to the 
antiproliferative activity of IFN- $\gamma$; in this context, it has been shown that the reduced levels of the IFN $\gamma$-R2 subunit can allow Th1 cells to proliferate during IFN- $\gamma$ signaling [51]. On the other hand, Th2 cells, that do not synthetize IFN- $\gamma$, produce increased levels of the IFN $\gamma-\mathrm{R} 2$ chain, rendering them particularly responsive to the antiproliferative activity of IFN- $\gamma$ [51]. Thus, the decrease in the expression of IFN $\gamma$-R1 and R2 chains on the synovial cells observed after IFN- $\gamma$ pretreatment could be a plausible regulatory mechanism by which these cells are desensitized in response to this proinflammatory cytokine, potentially reducing long-term tissue damage.

\section{Conclusions}

In conclusion, our data highlight the ability of IFN- $\gamma$ to interfere with the inflammasome network for C. trachomatis infection control in synovial cells. In fact, in the absence of IFN $\gamma, C$. trachomatis might evade the host cell immune response affecting the inflammasome pathway. On the downside, the presence of IFN $-\gamma$ might contribute to chronic inflammation by increasing proinflammatory cytokine production, potentially harmful for host cells. However, both the mechanism and functional relevance of IFN- $\gamma$ and the inflammasome network in C. trachomatis deserve more attention, and further studies are needed to better address the effects of $C$. trachomatis and IFN- $\gamma$ response on caspase- 1 activation in primary human synovial cells.

Supplementary Materials: The following are available online at https: / www.mdpi.com/article / 10.3390/life11121359/s1, Table S1: Analysis of variance (two-factor ANOVA) for the mRNA expression levels of selected inflammatory genes in different times after infection as well as infection conditions, Table S2: Analysis of variance (two-factor ANOVA) for the protein levels, via ELISA, of selected cytokines in different times after infection and infection conditions. Figure S1: Fluorescence microscopy pictures of $C$. trachomatis inclusion morphology in primary human synovial cells. Cells were infected with $C$. trachomatis at a MOI of 1.0 and stained with a FITCconjugated anti-C. trachomatis MOMP monoclonal antibody (Chlamydia Cell kit, Cellabs, Sydney, AU), as described in Materials and Methods. All pictures were taken at 36 h.p.i. Figure S2: Fluorescence microscopy pictures of $C$. trachomatis inclusions in primary human synovial cells. Cells were infected with $C$. trachomatis at a MOI of 1.0 and stained with the primary antibody anti-C. trachomatis LPS monoclonal antibody (Mab29, CT601, Chlamydia Biobank, UK) combined with a goat anti-Mouse IgG antibody conjugated with Alexa Fluor Plus-488 (Invitrogen, Thermo Fisher Scientific, USA). Wheat Germ Agglutinin conjugated with Alexa Fluor-594 (Invitrogen, Thermo Fisher Scientific, USA) was used for counterstaining cell monolayer. All pictures were taken at 36 h.p.i. Figure S3: Effect of pan-caspase inhibitor Z-VAD-FMK on primary human synovial cell viability. (a) MTT assay; (b) Viable cell count assay.

Author Contributions: Conceptualization, M.D.P., C.S. and R.S.; methodology, S.F., M.D.P., F.F., F.D. and M.S.; software, S.F.; validation, S.F., M.D.P. and F.F.; formal analysis, S.F., M.D.P., F.F. and M.S.; investigation, S.F., M.D.P., F.F., F.D., M.S. and R.S.; resources, G.A., C.S. and R.S.; data curation, S.F., M.D.P. and F.F.; writing-original draft preparation, S.F., M.D.P., C.S. and R.S.; writing-review and editing, S.F., M.D.P., F.F., F.D., M.S., C.S., G.A. and R.S.; visualization, S.F., M.D.P. and F.D.; supervision, C.S. and R.S.; project administration, R.S. All authors have read and agreed to the published version of the manuscript.

Funding: This research was funded by the University of Rome "Sapienza" to Prof. Rosa Sessa (grant number RP11916B6AEB0D37).

Institutional Review Board Statement: Not applicable.

Informed Consent Statement: Not applicable.

Data Availability Statement: Data is contained within the article or supplementary material.

Conflicts of Interest: The authors declare no conflict of interests. 


\section{References}

1. Rowley, J.; Vander Hoorn, S.; Korenromp, E.; Low, N.; Unemo, M.; Abu-Raddad, L.J.; Chico, R.M.; Smolak, A.; Newman, L.; Gottlieb, S.; et al. Chlamydia, gonorrhoea, trichomoniasis and syphilis: Global prevalence and incidence estimates, 2016. Bull. World Health Organ. 2019, 97, 548. [CrossRef] [PubMed]

2. Di Pietro, M.; Filardo, S.; Romano, S.; Sessa, R. Chlamydia trachomatis and Chlamydia pneumoniae Interaction with the Host: Latest Advances and Future Prospective. Microorganisms 2019, 7, 140. [CrossRef] [PubMed]

3. O'Connell, C.M.; Ferone, M.E. Chlamydia trachomatis Genital Infections. Microb. Cell 2016, 3, 390-403. [CrossRef]

4. Sessa, R.; Di Pietro, M.; De Santis, F.; Filardo, S.; Ragno, R.; Angiolella, L. Effects ofMentha suaveolensEssential Oil onChlamydia trachomatis. BioMed Res. Int. 2015, 2015, 508071. [CrossRef] [PubMed]

5. Di Pietro, M.; Filardo, S.; Alfano, V.; Pelloni, M.; Spendiani, E.; Po, A.; Paoli, D.; Ferretti, E.; Sessa, R. Chlamydia trachomatis elicits TLR3 expression but disrupts the inflammatory signaling down-modulating NFKB and IRF3 transcription factors in human Sertoli cells. J. Biol. Regul. Homeost. Agents 2020, 34, 977-986. [CrossRef] [PubMed]

6. Filardo, S.; Skilton, R.J.; O’Neill, C.; Di Pietro, M.; Sessa, R.; Clarke, I.N. Growth kinetics of Chlamydia trachomatis in primary human Sertoli cells. Sci. Rep. 2019, 9, 5847. [CrossRef]

7. Kumar, R.; A Derbigny, W. TLR3 Deficiency Leads to a Dysregulation in the Global Gene-Expression Profile in Murine Oviduct Epithelial Cells Infected with Chlamydia muridarum. Int. J. Microbiol. Curr. Res. 2018, 1, 1-13. [CrossRef]

8. Yu, P.; Xiao, L.; Lin, L.; Tang, L.; Chen, C.; Wang, F.; Wang, Y. STAT3-mediated TLR2/4 pathway upregulation in an IFN-gammainducedChlamydia trachomatispersistent infection model. Pathog. Dis. 2016, 74, ftw076. [CrossRef]

9. Kavathas, P.B.; Boeras, C.M.; Mulla, M.J.; Abrahams, V.M. Nod1, but not the ASC inflammasome, contributes to induction of IL-1 $\beta$ secretion in human trophoblasts after sensing of Chlamydia trachomatis. Mucosal Immunol. 2012, 6, 235-243. [CrossRef] [PubMed]

10. Buchholz, K.R.; Stephens, R.S. The Cytosolic Pattern Recognition Receptor NOD1 Induces Inflammatory Interleukin-8 during Chlamydia trachomatis Infection. Infect. Immun. 2008, 76, 3150-3155. [CrossRef]

11. Di Pietro, M.; Filardo, S.; Frasca, F.; Scagnolari, C.; Manera, M.; Sessa, V.; Antonelli, G.; Sessa, R. Interferon- $\gamma$ Possesses AntiMicrobial and Immunomodulatory Activity on a Chlamydia trachomatis Infection Model of Primary Human Synovial Fibroblasts. Microorganisms 2020, 8, 235. [CrossRef] [PubMed]

12. Gitsels, A.; Sanders, N.; Vanrompay, D. Chlamydial Infection From Outside to Inside. Front. Microbiol. 2019, 10, 2329. [CrossRef]

13. Panzetta, M.E.; Valdivia, R.H.; Saka, H.A. Chlamydia Persistence: A Survival Strategy to Evade Antimicrobial Effects in-vitro and in-vivo. Front. Microbiol. 2018, 9, 3101. [CrossRef] [PubMed]

14. Mastromarino, P.; Di Pietro, M.; Schiavoni, G.; Nardis, C.; Gentile, M.; Sessa, R. Effects of vaginal lactobacilli in Chlamydia trachomatis infection. Int. J. Med. Microbiol. 2014, 304, 654-661. [CrossRef] [PubMed]

15. Brewer, S.M.; Brubaker, S.W.; Monack, D.M. Host inflammasome defense mechanisms and bacterial pathogen evasion strategies. Curr. Opin. Immunol. 2019, 60, 63-70. [CrossRef]

16. Man, S.M.; Karki, R.; Kanneganti, T.-D. Molecular mechanisms and functions of pyroptosis, inflammatory caspases and inflammasomes in infectious diseases. Immunol. Rev. 2017, 277, 61-75. [CrossRef]

17. McAllister, M.; Chemaly, M.; Eakin, A.; Gibson, D.; McGilligan, V. NLRP3 as a potentially novel biomarker for the management of osteoarthritis. Osteoarthr. Cartil. 2018, 26, 612-619. [CrossRef] [PubMed]

18. Sellam, J.; Berenbaum, F. The role of synovitis in pathophysiology and clinical symptoms of osteoarthritis. Nat. Rev. Rheumatol. 2010, 6, 625-635. [CrossRef] [PubMed]

19. Wojdasiewicz, P.; Poniatowski, L.A.; Szukiewicz, D. The Role of Inflammatory and Anti-Inflammatory Cytokines in the Pathogenesis of Osteoarthritis. Mediat. Inflamm. 2014, 2014, 561459. [CrossRef]

20. Puren, A.J.; Fantuzzi, G.; Gu, Y.; Su, M.S.; Dinarello, C.A. Interleukin-18 (IFNgamma-inducing factor) induces IL-8 and IL-1beta via TNFalpha production from non-CD14+ human blood mononuclear cells. J. Clin. Investig. 1998, 101, 711-721. [CrossRef] [PubMed]

21. Dinarello, C.A. Interleukin-1beta, Interleukin-18, and the Interleukin-1beta Converting Enzymea. Ann. N. Y. Acad. Sci. 1998, 856, 1-11. [CrossRef] [PubMed]

22. Bakshi, R.K.; Gupta, K.; Jordan, S.; Chi, X.; Lensing, S.Y.; Press, C.G.; Geisler, W.M. An Adaptive Chlamydia trachomatis-Specific IFN- $\gamma$-Producing CD4+ T Cell Response Is Associated with Protection Against Chlamydia Reinfection in Women. Front. Immunol. 2018, 9, 1981. [CrossRef] [PubMed]

23. Ziklo, N.; Huston, W.M.; Taing, K.; Katouli, M.; Timms, P. In vitro rescue of genital strains of Chlamydia trachomatis from interferon- $\gamma$ and tryptophan depletion with indole-positive, but not indole-negative Prevotella spp. BMC Microbiol. 2016, 16, 286. [CrossRef]

24. Sessa, R.; Di Pietro, M.; Filardo, S.; Bressan, A.; Mastromarino, P.; Biasucci, A.V.; Rosa, L.; Cutone, A.; Berlutti, F.; Paesano, R.; et al. Lactobacilli-lactoferrin interplay in Chlamydia trachomatis infection. Pathog. Dis. 2017, 75, ftx054. [CrossRef] [PubMed]

25. Di Pietro, M.; De Santis, F.; Schiavoni, G.; Filardo, S.; Sessa, R. Resveratrol in Chlamydia pneumoniae-induced foam cell formation and interleukin-17A synthesis. J. Boil. Regul. Homeost. Agents 2013, 27, 509-518.

26. Jorgensen, I.; Bednar, M.M.; Amin, V.; Davis, B.K.; Ting, J.P.; McCafferty, D.G.; Valdivia, R.H. The Chlamydia Protease CPAF Regulates Host and Bacterial Proteins to Maintain Pathogen Vacuole Integrity and Promote Virulence. Cell Host Microbe 2011, 10, 21-32. [CrossRef] [PubMed]

27. Abdul-Sater, A.A.; Koo, E.; Häcker, G.; Ojcius, D.M. Inflammasome-dependent Caspase-1 Activation in Cervical Epithelial Cells Stimulates Growth of the Intracellular Pathogen Chlamydia trachomatis. J. Biol. Chem. 2009, 284, 26789-26796. [CrossRef] 
28. Xavier, A.; Al-Zeer, M.A.; Meyer, T.F.; Daumke, O. hGBP1 Coordinates Chlamydia Restriction and Inflammasome Activation through Sequential GTP Hydrolysis. Cell Rep. 2020, 31, 107667. [CrossRef]

29. Webster, S.J.; Brode, S.; Ellis, L.; Fitzmaurice, T.; Elder, M.J.; Gekara, N.O.; Tourlomousis, P.; Bryant, C.; Clare, S.; Chee, R.; et al. Detection of a microbial metabolite by STING regulates inflammasome activation in response to Chlamydia trachomatis infection. PLoS Pathog. 2017, 13, e1006383. [CrossRef] [PubMed]

30. Finethy, R.; Jorgensen, I.; Haldar, A.K.; de Zoete, M.R.; Strowig, T.; Flavell, R.A.; Yamamoto, M.; Nagarajan, U.M.; Miao, E.; Coers, J. Guanylate Binding Proteins Enable Rapid Activation of Canonical and Noncanonical Inflammasomes in Chlamydia-Infected Macrophages. Infect. Immun. 2015, 83, 4740-4749. [CrossRef]

31. Abdul-Sater, A.A.; Saïd-Sadier, N.; Padilla, E.V.; Ojcius, D.M. Chlamydial infection of monocytes stimulates IL-1 $\beta$ secretion through activation of the NLRP3 inflammasome. Microbes Infect. 2010, 12, 652-661. [CrossRef] [PubMed]

32. Walton, E.L. The inflammasome: Friend or foe in Chlamydia infection? Biomed. J. 2016, 39, 299-303. [CrossRef] [PubMed]

33. Detjen, K.M.; Farwig, K.; Welzel, M.; Wiedenmann, B.; Rosewicz, S. Interferon gamma inhibits growth of human pancreatic carcinoma cells via caspase-1 dependent induction of apoptosis. Gut 2001, 49, 251-262. [CrossRef] [PubMed]

34. Choi, C.; Jeong, E.; Benveniste, E.N. Caspase-1 Mediates Fas-Induced Apoptosis and is Up-Regulated by Interferon- in Human Astrocytoma Cells. J. Neuro-Oncol. 2004, 67, 167-176. [CrossRef] [PubMed]

35. Lin, X.Y.; Choi, M.S.K.; Porter, A.G. Expression Analysis of the Human Caspase-1 Subfamily Reveals Specific Regulation of the CASP5 Gene by Lipopolysaccharide and Interferon- $\gamma$. J. Biol. Chem. 2000, 275, 39920-39926. [CrossRef]

36. Khare, S.; Ratsimandresy, R.A.; De Almeida, L.; Cuda, C.; Rellick, S.L.; Misharin, A.; Wallin, M.C.; Gangopadhyay, A.; Forte, E.; Gottwein, E.; et al. The PYRIN domain-only protein POP3 inhibits ALR inflammasomes and regulates responses to infection with DNA viruses. Nat. Immunol. 2014, 15, 343-353. [CrossRef] [PubMed]

37. Brunham, R.C.; Rey-Ladino, J. Immunology of Chlamydia infection: Implications for a Chlamydia trachomatis vaccine. Nat. Rev. Immunol. 2005, 5, 149-161. [CrossRef] [PubMed]

38. Xiang, W.; Yu, N.; Lei, A.; Li, X.; Tan, S.; Huang, L.; Zhou, Z. Insights Into Host Cell Cytokines in Chlamydia Infection. Front. Immunol. 2021, 12, 1915. [CrossRef] [PubMed]

39. Wang, S.; Fan, Y.; Brunham, R.C.; Yang, X. IFN-Gamma Knockout Mice Show Th2-Associated Delayed-Type Hypersensitivity and the Inflammatory Cells Fail to Localize and Control Chlamydial Infection. Eur. J. Immunol. 1999, 29, 3782-3792. [CrossRef]

40. Megha, K.; Joseph, X.; Akhil, V.; Mohanan, P. Cascade of immune mechanism and consequences of inflammatory disorders. Phytomedicine 2021, 91, 153712. [CrossRef]

41. Eitel, J.; Meixenberger, K.; Van Laak, C.; Orlovski, C.; Hocke, A.; Schmeck, B.; Hippenstiel, S.; N'Guessan, P.D.; Suttorp, N.; Opitz, B. Rac1 Regulates the NLRP3 Inflammasome Which Mediates IL-1beta Production in Chlamydophila pneumoniae Infected Human Mononuclear Cells. PLoS ONE 2012, 7, e30379. [CrossRef] [PubMed]

42. Vardhan, H.; Dutta, R.; Vats, V.; Gupta, R.; Jha, R.; Jha, H.C.; Srivastava, P.; Bhengraj, A.R.; Mittal, A.S. Persistently Elevated Level of IL-8 inChlamydia trachomatisInfected HeLa 229 Cells is Dependent on Intracellular Available Iron. Mediat. Inflamm. 2009, 2009, 417658. [CrossRef] [PubMed]

43. Masters, S.; Mielke, L.; Cornish, A.L.; Sutton, C.E.; O’Donnell, J.; Cengia, L.H.; Roberts, A.; Wicks, I.P.; Mills, K.; Croker, B.A. Regulation of interleukin- $1 \beta$ by interferon- $\gamma$ is species specific, limited by suppressor of cytokine signalling 1 and influences interleukin-17 production. EMBO Rep. 2010, 11, 640-646. [CrossRef]

44. Bosco, M.C.; Gusella, G.L.; Espinoza-Delgado, I.; Longo, D.L.; Varesio, L. Interferon-Gamma Upregulates In-terleukin-8 Gene Expression in Human Monocytic Cells by a Posttranscriptional Mechanism. Blood 1994, 83, 537-542. [CrossRef] [PubMed]

45. Dinarello, C.A. Interleukin-1 and Its Biologically Related Cytokines. Adv. Immunol. 1989, 44, 153-205. [CrossRef] [PubMed]

46. Fenton, M.J.; Vermeulen, M.W.; Clark, B.D.; Webb, A.C.; Auron, P.E. Human pro-IL-1 beta gene expression in monocytic cells is regulated by two distinct pathways. J. Immunol. 1988, 140, 2267-2273. [PubMed]

47. Fenton, M.J.; Clark, B.D.; Collins, K.L.; Webb, A.C.; Rich, A.; Auron, P.E. Transcriptional regulation of the human prointerleukin 1 beta gene. J. Immunol. 1987, 138, 3972-3979. [PubMed]

48. Knudsen, P.J.; Dinarello, C.A.; Strom, T.B. Prostaglandins posttranscriptionally inhibit monocyte expression of interleukin 1 activity by increasing intracellular cyclic adenosine monophosphate. J. Immunol. 1986, 137, 3189-3194.

49. Huang, T.-J.; Li, Y.-Y.; Weng, Y.-J.; Cheng, C.-C.; Hsu, R.W.-W. Interleukin-6 Protein Expression Is More Important Than Interleukin-6 mRNA Levels in Assessing Surgical Invasiveness. J. Surg. Res. 2007, 142, 53-58. [CrossRef]

50. Ivanov, P.; Anderson, P. Post-transcriptional regulatory networks in immunity. Immunol. Rev. 2013, $253,253-272$. [CrossRef] [PubMed]

51. Castro, F.; Cardoso, A.P.; Goncalves, R.M.; Serre, K.; Oliveira, M.J. Interferon-Gamma at the Crossroads of Tumor Immune Surveillance or Evasion. Front. Immunol. 2018, 9, 847. [CrossRef] [PubMed] 